\title{
Adults changing careers through university education: Making meaning of quantitative career assessment scores through an integrative structured interview
}

\begin{tabular}{|c|c|}
\hline \multicolumn{2}{|c|}{$\begin{array}{l}\text { Authors: } \\
\text { Mary McMahon }{ }^{1} \text { (D) } \\
\text { Mark Watson }{ }^{2} \\
\text { Louis Zietsman }^{2}\end{array}$} \\
\hline \multicolumn{2}{|c|}{$\begin{array}{l}\text { Affiliations: } \\
{ }^{1} \text { School of Education, The } \\
\text { University of Queensland, } \\
\text { Australia }\end{array}$} \\
\hline \multicolumn{2}{|c|}{$\begin{array}{l}{ }^{2} \text { Department of Psychology, } \\
\text { Nelson Mandela University, } \\
\text { South Africa }\end{array}$} \\
\hline \multicolumn{2}{|c|}{$\begin{array}{l}\text { Corresponding author: } \\
\text { Mary McMahon, } \\
\text { marylmcmahon@uq.edu.au }\end{array}$} \\
\hline \multicolumn{2}{|c|}{$\begin{array}{l}\text { Dates: } \\
\text { Received: } 06 \text { Sept. } 2017 \\
\text { Accepted: } 17 \text { Jan. } 2018 \\
\text { Published: } 31 \text { May } 2018\end{array}$} \\
\hline \multicolumn{2}{|c|}{$\begin{array}{l}\text { How to cite this article: } \\
\text { McMahon, M., Watson, M., } \\
\text { \& Zietsman, L. (2018). Adults } \\
\text { changing careers through } \\
\text { university education: Making } \\
\text { meaning of quantitative } \\
\text { career assessment scores } \\
\text { through an integrative } \\
\text { structured interview. SA } \\
\text { Journal of Industrial } \\
\text { Psychology/SA Tydskrif vir } \\
\text { Bedryfsielkunde, 44(0), } \\
\text { a1487. https://doi.org/ } \\
\text { 10.4102/sajip.v44i0.1487 }\end{array}$} \\
\hline \multicolumn{2}{|c|}{$\begin{array}{l}\text { Copyright: } \\
\text { (C) 2018. The Authors. } \\
\text { Licensee: AOSIS. This work } \\
\text { is licensed under the } \\
\text { Creative Commons } \\
\text { Attribution License. }\end{array}$} \\
\hline \multicolumn{2}{|l|}{ Read online: } \\
\hline 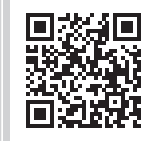 & $\begin{array}{l}\text { Scan this QR } \\
\text { code with your } \\
\text { smart phone or } \\
\text { mobile device } \\
\text { to read online. }\end{array}$ \\
\hline
\end{tabular}

Orientation: Career change in adulthood is becoming a norm and university education is a pathway to new careers. Career psychologists are well positioned to assist adult career changers. Contemporary approaches to diverse client groups and integrating career assessment with narrative career counselling are needed.

Research purpose: This article reports on an innovative approach to assisting adult career changers through the complementarity of an integrative structured interview (ISI) and the self-directed search (SDS) career assessment questionnaire.

Motivation for the study: The overall aim of this research was to explore the career transition experiences of adult university learners. The secondary aims were to investigate the complementarity of quantitative career assessment (i.e. the SDS) and narrative interviewing (i.e. the ISI) and how adult university learners engaged with the ISI. This article reports on the secondary aims by considering excerpts from case study interviews.

Research design, approach and method: This qualitative, exploratory, descriptive, multiple case study research presents case studies of two adult university learners: an Australian male student and a South African female student. Participants completed the SDS prior to engaging in a four-part semi-structured interview that incorporated the ISI.

Main findings: The findings revealed that the participants told rich stories that related past, present and future life and work experiences to their SDS three-letter codes. Their stories revealed how quantitative career assessment scores and narrative career counselling may be integrated through a structured interview.

Practical and managerial implications: Adult career changers told meaningful stories about their quantitative SDS scores. The findings suggest that narrative career counselling may be useful for adult career changers and that the ISI could provide a model for career psychologists who support them. Implications of the findings suggest that managers and human resource personnel working in organisations may assist adult career changers by offering them access to psychological support that uses quantitative career assessment as a foundation for career story telling.

Contribution or value-add: The research provides an innovative response to challenges in career psychology to develop contemporary responses to diverse client groups and to integrate career assessment with narrative career counselling.

\section{Introduction}

Career change has become commonplace as the world of work has moved away from stability and permanency to fluidity (Watson \& Stead, 2017). Globalisation, along with technological, organisational and social change, is resulting in a world of work that expects, and causes, the workforce to become more mobile (Chesters, 2014; Gubler, Arnold, \& Coombs, 2014). Concomitant with career change is the need for workers to upskill and re-skill to keep pace with change by engaging and re-engaging in learning across their working lives. Learning in adulthood can:

... transform lives, fire new enthusiasms and satisfy old curiosities. It can be a route to gain or maintain employment, and the means to sustain livelihood. It can offer second chances to people who missed out in their earlier education, and first chances to people who never had the chance to go to school (Tuckett, 2017, p. 230).

Increasingly, career changers (adults changing from one occupational group to another with the resultant need to acquire new skills and knowledge) are choosing university education as a 
pathway to a new career; 'age is not a barrier to improving one's human capital and enjoying the economic rewards of doing so' (Chesters \& Watson, 2014, p. 1643). For example, in the United States of America, older university students have increased to $43 \%$ of the university student population (Caruth, 2014). According to the Higher Education Statistical Agency (2012/13), 20.7\% of the United Kingdom (UK) domiciled entrants on full-time first degree courses were aged 21 and over, $52.6 \%$ on full-time other undergraduate courses were aged 21 and over, and $54.4 \%$ of part-time first degree entrants were aged 30 or over. In Australia, $41 \%$ of higher education students were aged 25-64 years (Australian Bureau of Statistics, 2013). Of these students, nearly 6 out of $10(57 \%)$ already had a bachelor's degree and were either improving the level of their qualification or retraining or broadening their education. Of the students who already had a bachelor's degree or above, three in five $(61 \%)$ students were enrolled into a postgraduate degree (Australian Bureau of Statistics, 2013). In South Africa, over one-third (35.4\%) of all enrolments in higher education in 2013 were above 25 years of age, with $17.4 \%$ of all enrolments being above 35 years of age (Council of Higher Education, 2013). The enrolment of students over the age of 25 years in higher education in South Africa had grown to $43.2 \%$ by 2015 (Council of Higher Education, 2017), with 15.7\% of all enrolments being above 35 years, largely as a result of policy initiatives that have encouraged both lifelong learning and greater access into higher education.

Differences are apparent between the older student cohort and their younger counterparts. For example, $90 \%$ of younger Australian students were studying full-time in 2012, compared with fewer than half (42\%) of older students. Younger students were more likely to study fulltime and work part-time or not work at all, while older students were more likely to study part-time and work fullor part-time. Earning a wage or salary was the main source of income for three out of five (61\%) higher education students, with this trend being more evident for older students $(67 \%)$ than younger students $(56 \%)$ (Australian Bureau of Statistics, 2013).

Adults engage in university education for a number of reasons including obtaining a first or advanced degree qualification, changing careers, strengthening work skills or learning new skills and knowledge (Chesters \& Watson, 2014; Hardin, 2008). For whatever reason adults enter university education, such a transition constitutes a major life change (Hardin, 2008). As with any career decision, transitioning to university education or to a new career through a university education pathway is subject to a range of influences including the interaction of multiple life roles (Schooreel, Shockley, \& Verbruggen, 2017). For example, adults, unlike school leavers, may have a family to support financially and emotionally, while incurring the time and cost of university education and the possibility that their career move may not be cost-effective or a guarantee of employment. Australian research, however, has found that in the year after graduation, students aged 25 or over were more likely to be employed full-time, and on average earned more than younger graduates (Chesters \& Watson, 2014). By the third year after graduation there was no difference in earnings between the two groups, suggesting that return on investment may be lower for older students although further long-term research is needed (Chesters \& Watson, 2014).

Some adult learners may be paying for their university education while also experiencing a reduction in income (Montgomery, Tansey, \& Roe, 2009). Adult learners tend to have more unpredictable transitions into university than their school leaver counterparts (Stevenson \& Clegg, 2013), and their decision to change careers may be a personal choice or brought about by external, and sometimes unexpected, events such as corporate downsizing or redundancy. Regardless, changing careers in adulthood involves a complex range of personal, familial, financial and learning challenges (Jain, 2014). Career change is not, however, purely a cognitive process. Rather, it may be accompanied by a diversity of emotions such as excitement, anticipation, hope, trepidation, concern, worry and fear (Bimrose \& Hearne, 2012). The interplay between familial, career and student roles leads to some adult university students experiencing feelings of anxiety and guilt (Fragoso et al., 2013). Moreover, the complexity of career decisions and transitions in adulthood suggests that career support may be beneficial to adult career changers (Jain, 2014). To date, however, only limited research has been conducted about this emerging and growing cohort and even less research has investigated possible means by which career psychologists may support them. Career psychology, however, has tended to rely on approaches emanating from the mid-20th century, and concerns have been expressed for over two decades about the relevance of such approaches, and calls have been made for innovative approaches that can be integrated into contemporary practice (Sharf, 2013). Consequently, career psychology is seeking contemporary approaches to respond to diverse client groups and to integrate career assessment with narrative approaches to career counselling (Zytowski, 2015) so that 'typically objectively measured traits' are not artificially separated 'from subjectively experienced personal and emotional life' (Rottinghaus \& Eshelman, 2015, p. 25).

The purpose of this article is to consider how adult career changers engaging in university education may be supported by career psychologists to make meaning of their complex decisions and transitions in the context of their lives.

\section{Research purpose and objectives}

The overall aim of this exploratory descriptive research was to explore the career transition experiences of adult university learners through a complementary qualitative and quantitative process. Related to this aim were the secondary aims of gaining insight into the complementarity of quantitative career assessment [i.e. the (self-directed search (SDS)] and narrative interviewing [i.e. the integrative 
structured interview (ISI)] and to investigate how adult university learners engaged with the ISI. This article reports on the secondary aims by considering excerpts of case study interviews.

This research contributes to the field of career psychology in several ways. Firstly, it makes a theoretical contribution by providing better understanding of how quantitative career assessment scores and narrative career counselling may be integrated through a structured interview. Secondly, the research raises awareness of and provides some insight about an emerging cohort that to date has been little researched in career psychology. Thirdly, at a more practical level, the research demonstrates a process that could be applied and adapted by career psychologists in their work with adult career changers in order to assist them with their career decisions and transitions.

Literature related to career support for adults is reviewed and the ISI proposed as a potential means of such support. Subsequently, the research design will be described following which two case studies will be presented to illustrate the participants' engagement with the ISI and how quantitative career assessment may be storied through a narrative interview process. The article concludes with a discussion that includes practical implications for career psychologists and limitations and recommendations.

\section{Literature review}

In an era where lifelong learning and career change are norms and increasing numbers of adults are considering university education, career psychologists are well positioned to assist adult career changers with their career decisions and to support them to successfully manage their transitions (Barabasch, Merrill, \& Zanazzi, 2015) and explore learning opportunities (Bimrose \& Brown, 2014). Indeed, in this era of repeated career change in adulthood, the role of career professionals is critical (Jain, 2014). Central to changing careers is developing a clear sense of direction, and this is best achieved through self-reflectivity (Bimrose, Barabasch, Brown, \& Mulvey, 2015); a process of self-reflection may be facilitated in career counselling (Bimrose et al., 2015, p. 257) by career psychologists.

Given the importance of self-reflection by clients in career counselling, career psychology has been challenged to adapt its career counselling models and assessment (Bimrose \& Brown, 2014; Savickas, 1993) in order to cater to more diverse client groups including older adults and to respond to the growing influence of constructivism and social constructionism in career theory and practice. A particular challenge has been to exploit the potential complementarity of career psychology's expertise in assessment and the narrative counselling processes advocated by constructivism and social constructionism (McMahon \& Watson, 2012; Rottinghaus \& Eshelman, 2015; Sampson, Peterson, Osborn, \& Hayden, 2015; Watson, 2017; Watson \& McMahon, 2014, 2015; Zytowski, 2015), an example of which has previously been described in the South African context (see McMahon, Watson, Chetty, \& Hoelson, 2012b). A related challenge has been the limited guidance provided for career psychologists who wish to adopt narrative methods and the resultant uncertainty about how to engage in narrative practice (Reid, 2017). A response to these challenges has been the development of the ISI (McMahon \& Watson, 2012), which incorporates quantitative career assessment instruments such as the SDS (Holland, 1985) into a guided reflective narrative interview, the ISI (see Appendix 1), that provides a structure for career psychologists.

The ISI (McMahon \& Watson, 2012) is a series of questions that career psychologists may use to encourage clients to reflect on their quantitative scores obtained from career instruments such as the SDS (Holland, 1985) and Super's Work Values Inventory-Revised (Zytowski, 2006). The focus of this article is the ISI for the SDS (a detailed description of the ISI is given later in this article). In clients' responses to these questions, they experience a reflective learning process by telling rich systemic stories that help them to make meaning of their quantitative scores in the contexts of their lives. The telling of systemic stories enables clients to contextualise their quantitative scores in the multiple contexts of their lives and also in the contexts of their past, present and future. Through this narrative process, clients speak for considerably more time in the ISI (McMahon, Bimrose, Watson, \& Abkhezr, submitted) than career psychologists who assume a facilitative role. The ISI is theoretically grounded in the Systems Theory Framework of career development (STF; Patton \& McMahon, 2014), which presents a diverse range of contextual influences that may impact career decisions and transitions. Based on systems theory, the STF is a systemic map that depicts the complex and dynamic nature of an individual's career development through a series of interconnected systems and processes. Central to the STF is the individual system which comprises intrapersonal influences of the individual such as ability, personality and gender. Closely connected with the individual is the social system of influences such as family, friends and work colleagues. Also influencing the individual's career development are influences such as socio-economic circumstances and geographic location from the broader environmental-societal system in which the individual lives. The interconnected individual, social and environmentalsocietal systems are set within the context of past, present and future time. The dynamic, changing and interconnected processes of the STF are evident through the processes of recursiveness (i.e. the interaction between influences), change over time and chance.

Consistent with its theoretical underpinning, the ISI elicits systemic stories about clients and their career influences from each of the STF's systems of influence. In addition, systemic stories reveal the STF's process influences such as recursiveness (i.e. the interaction between influences), change over time and chance. Practical applications of the STF such as the ISI assume a 'person in context' (McMahon, Watson, \& Patton, 2014, p. 35) perspective and emphasise 
the quality of the working alliance so that clients feel safe and supported in the telling of their stories. In the case of the present research, a safe environment was ensured by its ethical conditions such as voluntary participation, confidentiality and anonymity.

In addition to the ISI, another practical application of the STF, that is, the storytelling approach to narrative career counselling, is relevant to the present research because its underpinning constructs are also foundational to the ISI (McMahon \& Watson, 2010, 2012). Consistent with other narrative approaches to career counselling, the storytelling approach recognises as core process constructs (1) the personal agency of individuals to tell stories about and (2) to make meaning of their experiences (McMahon \& Watson, 2010,2012). Storytelling facilitates the core process construct of (3) connectedness through making explicit relationships and interconnections within and between influences (McMahon, Watson, Chetty, \& Hoelson, 2012a, 2012b). Distinguishing the storytelling approach from other narrative career counselling approaches are the core process constructs of (4) reflection and (5) learning, both of which are explicitly incorporated as important elements of the career counselling process (McMahon et al., 2012a). (For a more detailed description of the storytelling approach and the process constructs, see McMahon et al., 2012b.) The STF and the core process constructs of the storytelling approach informed the development of the ISI in terms of its section structure and questions, which will be described later in this article.

\section{Research Design}

\section{Research approach}

This research investigated phenomena about which little is known. One phenomenon is that of adult university students who represent an emerging and growing cohort about which further research is needed. A further phenomenon is that of integrating quantitative career assessment with narrative interview processes. Qualitative research is well suited to investigating phenomena about which little is known (Marshall \& Rossman, 2014). The assumptions underlying this research were informed by social constructionism, which assumes that individuals make meaning of their experiences through social and cultural interaction with others. Thus, a goal of this qualitative research was to elicit participants' perspectives, personal meanings and subjectivities on their experiences of university education and of their SDS scores.

\section{Research strategy}

Consistent with the underlying assumptions of the present research, an exploratory multiple case study method was employed. Exploratory case studies are also useful for exploring phenomena about which there is not a clear outcome as in the case of the present research (Yin, 2014). Multiple case studies replicate the research procedure with each case and enable comparisons to be made across cases while recognising and valuing the individual cases.

\section{Research method \\ Research setting}

The research was conducted in the contexts of a large Australian university and a South African university. The Australian university comprises over 50000 students of whom slightly more than half are female students and almost one-third are international students (from 141 countries). Most of the students are enrolled as full-time internal students across six faculties. The university has a strong reputation in research and teaching. The South African university comprises over 26000 students of whom 53\% are female students and 5\% (from 63 countries) are international students. The university has seven faculties and has a good reputation for both research and teaching.

\section{Entrée and establishing researcher roles}

The first and the second researchers have extensive experience in narrative career counselling and qualitative career assessment research. Their recent research has focused on developing ways of integrating quantitative career assessment and narrative career counselling with a view to providing practical approaches that can be used by career psychologists. The first and the second researchers are the developers of the ISI used in this research and were responsible for conceptualising the research project design. The first researcher was responsible for the project in Australia and collected the Australian data. The second researcher was responsible for the research project in South Africa. The third researcher is a beginning researcher developing skills in qualitative career research and collected data for the project in South Africa. As the research was being conducted in two countries, the researchers maintained contact via email and Skype.

\section{Sampling}

The non-probability strategy of purposive sampling was employed to ensure that participants met the inclusion criteria, specifically that they were at least 21 years of age, had worked for at least 2 years full-time prior to commencing their university education and were in their final year of undergraduate education.

Following ethical approval from the universities' ethics committees, information about the research was provided to students in their final year of undergraduate education in a behavioural and social sciences department of both the South African and Australian universities. Students who were interested in participating contacted the researchers and were subsequently provided with Participant Information Sheets and Consent Forms. Participation was voluntary and only those who signed the consent forms took part in the research. Anonymity and confidentiality were assured, and participants were free to withdraw from the research at any time without penalty.

\section{Participants}

The Australian participant was a 35-year-old male university student called Michael (pseudonym). He was married with 
two children and was enrolled in the final year of his degree. He had left school at age 17, attended university for 1 year, dropped out and had been employed for most of his life since that time. Michael's scores for each code were R (22), I (26), A (16), S (24), E (21) and C (27); so his three-letter code was CIS based on his three highest scores. Because there was little difference between five of his six scores, his profile could be regarded as undifferentiated, which could mean that he may have broad interests or more difficulty identifying preferred career options. Prior to returning to university, Michael had worked in a skilled technical role that was coded realistic, investigative and enterprising (RIE) according to Holland's Occupations Finder (Shears \& Harvey-Beavis, 2006). The career he hoped to enter after graduating from university was coded social, investigative and conventional (SIC).

The South African participant was a 24-year-old female university student called Fiona (pseudonym). She was married with one child and was enrolled part-time in the final year of her degree. She attended university after leaving school and gained a professional degree. Fiona's scores for each code were R (12), I (25), A (31), S (52), E (44) and C (37); so her three-letter code was SEC based on her three highest scores. Fiona's highest score demonstrates differentiation from her other five interest scores and her three-letter code is fairly differentiated from her remaining three interest scores. Prior to returning to university, Fiona had been employed in a profession coded social, investigative, and conventional (SIC) according to Holland's Occupations Finder. The career she hoped to enter after graduating from university was coded social, investigative, and artistic (SIA) according to Holland's Occupations Finder (Shears \& Harvey-Beavis, 2006).

\section{Data collection methods}

Two instruments were employed in the present research, the SDS and the ISI which was embedded in a larger semistructured interview for the purposes of the research.

The SDS (Holland, 1985) is one of the most widely used career assessment instruments in the world. A strength of the SDS is that, as its name implies, users may work their way through the assessment guided by the instructions in the assessment booklet. As a quantitative career assessment instrument, users receive scores across six typologies upon completion. The three highest scores are used to provide users with a three-letter code based on the six personality types identified in Holland's (1997) theory of vocational personalities and work environments, specifically Realistic, Investigative, Artistic, Social, Enterprising and Conventional (represented by the acronym RIASEC). The Realistic type shows an interest in working with objects, tools and machinery. This often leads to the mastery of manual skills and the development of practical and physical interests. The Investigative type indicates a preference for the systematic investigation of physical, biological and cultural matters. This often leads to the mastery of scientific and mathematical skills. The Artistic type prefers using creativity and artistic skills. This often leads to the mastery of artistic skills, irrespective of whether they relate to language, art, music or drama. The Social type shows a preference for working with people by forming and training them, or by caring for them. This often leads to the mastery of interpersonal and educational skills. The Enterprising type shows a preference for manipulating people, for taking the lead and for acting in an enterprising way in the business world or in public life. This often leads to the mastery of leadership skills, good interpersonal abilities and persuasive abilities. The Conventional type shows a preference for ordered activity that includes the manipulation of data. This often leads to the mastery of clerical and computational skills. Scores for a particular type can range from 2 to 48. According to Holland (1985, 1997), occupations may also be classified according to these six categories and so, on the basis of their three-letter code, individuals may match their code to those of occupations with the same three-letter code.

For the purposes of this research, the ISI process for the SDS was embedded in a larger semi-structured interview that comprised four parts. Part 1 of the interview contained five questions about demographic information such as age, marital status, dependents and previous and future employment. Part 2 contained seven questions about the participant's programme of study and career aspirations. Part 3 contained the ISI for the SDS. Part 4 contained eight questions about transitioning from university. The focus of this article is on Part 3.

The ISI (McMahon \& Watson, 2012; Watson, 2017; Watson \& McMahon, 2014) comprises six sections from which stories are crafted in response to the questions contained within the sections (see Appendix 1 for the ISI). The six sections are (1) crafting a story about the quantitative scores, (2) crafting a story about the relative value of the quantitative scores, (3) crafting a story about the quantitative scores in life contexts, (4) crafting a story about the quantitative scores in work contexts, (5) crafting a story about the quantitative scores through personal reflection and (6) crafting an integrative future story using the quantitative scores and past and present experience. In addition to the 13 specific ISI questions, interviewers may use further probes, questions and reflections to encourage clients to fully elaborate their stories.

\section{Procedure}

Subsequent to agreeing to participate in the research, the participants were provided with a copy of the SDS by the researchers which they completed prior to the interview. Interviews were conducted at a time and place agreed by the participants and the researchers and were conducted in Australia by the first author and in South Africa by the third author. The duration of the Australian interview was approximately $48 \mathrm{~min}$, and it was approximately $38 \mathrm{~min}$ for the South African interview. 


\section{Data recording}

The SDS forms of each participant were photocopied, and the originals were returned to the participants. Photocopies were stored in locked filing cabinets accessible only to the researchers. The ISI interviews were audio-recorded, transcribed and stored on password-protected computers accessible only to the researchers.

\section{Strategies employed to ensure data quality and integrity}

Trustworthiness was established through Lincoln and Guba's (1985) criteria of credibility, transferability, dependability and confirmability. Credibility was enhanced through voluntary participation and rapport building to encourage honest and open answers. In addition, participants were provided with a copy of their transcript for checking and neither requested any changes. Transferability of the research was enhanced by offering a detailed description of the methods used and the case studies to ensure that readers have enough detail to be able to relate to the research and make connections with their own experiences. Dependability was achieved through a detailed description of the research. Confirmability was ensured through the presentation of the findings as case studies that allowed the words of the participants to be presented without interpretation by the researchers. Participation in the research was voluntary, and participants were free to withdraw from the research at any time without penalty. All participants provided informed consent. Anonymity and confidentiality were assured through the use of pseudonyms, by the removal of identifiable data and by changing details such as ages and programmes of study where appropriate.

\section{Data analysis}

For the purposes of this article, excerpts from the transcripts of each participant were selected that best illustrated the stories crafted by the participants during each of the six sections of the ISI interviews.

Reporting style: The data will be reported as case studies according to the six sections of the ISI and the stories constructed in those sections. Excerpts of the participants' stories will be provided to illustrate the complementarity of quantitative scores and a narrative interview process. The case study of Michael will be presented first followed by that of Fiona.

\section{Findings}

\section{Michael's stories}

\section{Crafting a story about the code letters}

In this section of the ISI, Michael crafted stories about each of his scores that were based on his work and life experiences, and this occupied 30 lines of text in the transcript:

The hardest one for me was the S. Conventional ... makes a lot of sense to me... I've always been doing computer stuff ... you know I was doing data entry and learned to touch type because I code, and being able to touch type or coding ... That's what I do. That's how my head works. So that didn't surprise me at all.
Being Investigative, obviously you like to set up to discover, rediscovered my love of mathematics, which is being awesome. That's obviously where the Investigative comes from. You know, just solving problems and figuring things out. I mean, when I was working, doing logistics was fun ... Solving these little puzzles, so that was where the Investigative comes from. The Social threw me because I am not social at all. I am socially very awkward ... I'll go to a party and listen to people there, you know, I tend to sit off the side. But when I looked at the description 'agreeable, cooperative and empathetic, friendly, generous, hopeful', I would probably say that I would definitely fit with all those things ... I am very cooperative ... I've been told I am very empathetic, and I can be quite understanding....

\section{Crafting a story about the code order}

In this section of the ISI, the one question invites participants to rank their scores from 1 to 10 in order of importance where 10 is the most important. Michael explained:

I probably put the $C \ldots$ at 6 or $7 \ldots$ that's just the stuff that I do it everyday. That's the simple ... The I? I probably put it higher up towards at 8 or 9 . Yeah, I consider the Investigative part pretty important. That's the challenges, the frustrations. It's also the rewarding part. And you know, I guess, the S, I probably put it, probably at 8 as well. I think the two are emotional and rewarding things....

\section{Crafting a story about the code letters in life contexts}

In this section of the ISI, the excerpt illustrates how Michael storied the I of his three-letter code in the context of his previous work experience:

I started working with engineers in my own job ... They were showing me a model that was not going to work ... I was always pretty good with math, and I kind of sat down with them and was able to look at the models and just go, 'Well, this didn't work because it is, so if you change this ...' you know, solving these problems. That's where I came in ... my team leader's boss figured out very quickly that the joy of having me work with them was I may not turn out as much product as everybody else as I know, but the product I turned out was perfect ... You know I was running a machine in a factory ... But for me, it was a case, yeah, anyone can do it, but what I am going to do is I am going to make it the best I can. So that was the Investigative part for me.

\section{Crafting a story about the code letters through personal reflection}

In this section of the ISI, Michael explained that:

I have a strong sort of principle that I stick to ... setting an example for the kids and I guess showing them, you know, the good things in life and these fun things in life outside school ... when they leave school, there are always opportunity for them to go and do these amazing things in life.

\section{Crafting a story about the code letters in work contexts}

In this section of the ISI, Michael reflected elements of his previous job which he regarded as conventional and said:

So I guess the least rewarding before was just that it became routine ... I don't really want to do this routine over and over for the next 15, 20 years. You know, there were chances and other opportunities from there, but not really, not really really big ones. 
Not ones ... I really want to be going to do that for the rest of my life. So coming back to study definitely was a better option for me.

\section{Crafting an integrative future story using the self-directed search code and past and present experience}

In this section of the ISI, Michael considered his preferred future career and the importance of his I and S codes when he said:

Investigative, I am going to do math ... You kind of use the investigative skills to go, 'Alright, is there another way I can explain to make this make sense?' So yeah, definitely the $\mathrm{S}$ and the I are going to be very important, going forward. And probably, you know, I guess it's somewhat arrogant to say, but it does feel good when ... you try something different ... that works ...

\section{Fiona's stories}

\section{Crafting a story about the code letters}

In this section of the ISI, Fiona reflected her pleasure at having $S$ in her three-letter code as evidenced in the following excerpt:

... so I am quite happy that my highest was social because I do see myself as helping others, guiding especially in the choices I have made so far with my studying ... especially because you are working with people as well.

Fiona found it more difficult to relate to the $\mathrm{E}$ and concluded that in her present job:

'[I] end up leading people and taking the leadership role so I do think enterprising is suited.

\section{Crafting a story about the code order}

In this section of the ISI, when asked about the order of her code, Fiona concluded that:

... social would be exactly where it is right now - the highest and I actually agree with the order of my code because it makes more sense with the career that I'm in and the degree I'm studying so I will leave it as is.

\section{Crafting a story about the code letters in life contexts}

In this section of the ISI, Fiona was readily able to make sense of her three-letter code in a number of contexts as reflected in the following excerpt:

... if I go way back, when I was working casually at certain places while I was studying, one place was a clothing store, so I was working with people, socialising with people, interacting with them. The next place was at a gym, so I was with people as well and that is where conventional and enterprise type will fall in as well. So I have been a receptionist at a gym for quite a while and then a .... So it is quite evident in my career and in my studies what my code standing is.

\section{Crafting a story about the code letters through personal reflection}

In this section of the ISI, Fiona considered her personal qualities in relation to her $\mathrm{S}$ code in the following excerpt:

I feel I should be more of an outgoing person in my career and my studies in a sense that people can relate to me and talk to me, like I have always said somehow there is written on my forehead talk to me ... I will find myself e.g., sitting ... and then someone would open up and talk ... if you are not an open and friendly person people would shy away from you, they wouldn't feel like they can approach you.

\section{Crafting a story about the code letters in work contexts}

In this section of the ISI, Fiona identified elements of her work related to the $\mathrm{S}$ code as most satisfying and elements related to her $\mathrm{C}$ code as least satisfying in the following excerpt:

With my past and current and future I think the most satisfying is the social interaction with people, the one-on-one, or group setting ... and caring for others, that part that is for me important. But the tiny things like admin things ... you have to catch up on certain deadlines, that for me is ... is the least important.

\section{Crafting an integrative future story using the self-directed} search code and past and present experience

In this section of the ISI, Fiona reflected on the satisfaction of having a backup plan as a result of her current study:

I see myself doing a couple of things for me to be satisfied. Like [current occupation] for me is satisfying and I am quite happy with that if not, a backup plan or something to fall back on. That is why [current course of study], that for me, in future, will be satisfying. I don't know why but I am picturing it as starting off on quite a high and maybe when I am quite mature people will feel like more that they can trust me and relate to me ... Somehow I am picturing my life like this.

\section{Discussion}

As evidenced in the case studies, both participants were readily able to engage with the ISI and respond to questions about their SDS scores.

\section{Outline of the findings}

Noticeable in both interviews was the agentic role of the participants in telling their stories and the greater proportion of the interview time spoken by them. The ISI questions fostered a reflective space in which the participants could think about their scores in the context of their work and life experiences. In essence, the ISI offers a response to the seminal call by Mark Savickas (1993) to move from scores to stories and to the challenge of developing integrative approaches to career intervention (Rottinghaus \& Eshelman, 2015). In the excerpts presented, the participants' experience of career change as both a cognitive and emotional experience was evident and reflects the findings of previous qualitative research into adult career counselling (e.g., Bimrose \& Hearne, 2012); participants were not only able to cognitively understand their career changes but also able to express their feelings about those changes. Their responses to the ISI questions evidence how they were able to make meaning of their quantitative scores through the stories that they told. Through relating their codes to specific work or life experiences, both participants facilitated connectedness between their scores and their lives. By doing so, the 
participants personalised the meaning of their scores rather than relying on theoretical explanations. Furthermore, in making meaning of their scores the participants learned more about themselves and were able to relate such learning to their career decisions; the ISI interview became a learning opportunity, which is a desirable element of career guidance with adult career changers (Bimrose \& Brown, 2014). Although the stimuli for the interviews were the quantitative SDS scores, the process constructs of the storytelling approach to narrative career counselling, that is, reflection, connectedness, meaning making, learning and agency (McMahon et al., 2012a), were clearly evident in the interviews. This finding is consistent with a South African research which integrated career assessment with narrative career counselling (McMahon et al., 2012b).

The ISI enabled a comfortable integration of the quantitative career assessment traditions of psychology with more contemporary narrative approaches and exploited their complementarities and thus addressed a need in the field for integrative approaches (Zytowski, 2015). A rich process of systemic storytelling was stimulated by the ISI in which the participants contextualised their SDS scores in relation to past and present experiences in a range of settings. The ISI moved 'from thin stories to thick and rich stories' (McMahon \& Watson, 2010, p. 53), which is consistent with narrative approaches to career counselling. In essence, the thin stories of the SDS scores which were the stimulus for the ISI became the themes around which the rich systemic stories were constructed. Thus, unlike narrative career counselling which seeks to identify themes from the content of clients' stories, the ISI predetermines themes through the SDS scores, which are elaborated through the interview. It should be noted, however, that this does not preclude the identification of other themes that may emerge from the stories.

\section{Practical implications}

This research attests to the potential of the ISI to integrate quantitative scores with qualitative stories told by participants and suggests that it may assist adult career changers to better understand their career decisions and transitions. Relating quantitative career assessment scores to past, present and future life and work experiences may assist adult career changers to make meaning of their career decisions and transitions. Career psychologists who facilitate narrative processes related to quantitative scores may provide their clients with a valuable experience of meaning making. While ISIs are available for the SDS and the Super's Work Values Inventory-Revised (SWVI-R), career psychologists could use the overarching structure of the ISI as a guide to developing similar interviews for other forms of quantitative career assessment.

\section{Limitations and recommendations}

Although the number of participants in this research was limited, the excerpts presented in the case studies provide a detailed picture of the potential of the ISI to elicit rich stories from users and in doing so illustrate how quantitative career assessment may be integrated with a narrative interview process. The research was not, however, a career counselling intervention, although the case studies suggest that adult career counselling clients may be similarly able to engage in ISI interviews. Future research could investigate the use of the ISI with larger samples and in career counselling interventions with adult career changers.

\section{Conclusion}

This small-scale qualitative research addressed pressing issues in career psychology, specifically the need to cater to diverse client groups and to find ways to integrate quantitative career assessment with narrative career counselling. The story crafting questions of the ISI facilitated a rich storytelling process during which participants made meaning of their quantitative career assessment scores. The research lends support to the complementarity of quantitative career assessment and narrative career counselling.

\section{Acknowledgements}

The second author (M.W.) would like to acknowledge grant holder funding from the National Research Foundation.

\section{Competing interests}

The authors declare that they have no financial or personal relationships that may have inappropriately influenced them in writing this article.

\section{Authors' contributions}

M.M. was responsible for the project in Australia and collected the Australian data. M.M. and M.W. conceptualised the research design. M.W. was responsible for the research project in South Africa. L.Z. collected data for the project in South Africa.

\section{References}

Australian Bureau of Statistics. (2013). Hitting the books: Characteristics of higher education students. Australian Bureau of Statistics. Retrieved from http://www. abs.gov.au/AUSSTATS/abs@.nsf/Lookup/4102.0Main+Features20July+2013

Barabasch, A., Merrill, B., \& Zanazzi, S. (2015). Structural support, networking and individual survival: Career changes in Italy and Spain. British Journal of Guidance \& Counselling, 43, 323-336. https://doi.org/10.1080/03069885.2015.1028889

Bimrose, J., Barabasch, A., Brown, A., \& Mulvey, R. (2015). Editorial: Midcareer changes symposium. British Journal of Guidance \& Counselling, 43, 255-262. https://doi.org/10.1080/03069885.2015.1037098

Bimrose, J., \& Brown, A. (2014). Mid-career progression and development: The role for career guidance and counseling. In G. Arulmani, A. J. Bakshi, F. T. L. Leong, \& A. G. Watts (Eds.), Handbook of career development: International perspectives (pp. 203-222). Dordrecht, The Netherlands: Springer.

Bimrose, J., \& Hearne, L. (2012). Resilience and career adaptability: Qualitative studies of adult career counseling. Journal of Vocational Behavior, 81, 338-344. https:// doi.org/10.1016/j.jvb.2012.08.002

Caruth, G.D. (2014). Meeting the needs of older students in higher education. Participatory Educational Research, 1(2), 21-35. https://doi.org/10.17275/ per.14.09.1.2

Chesters, J. (2014). Learning to adapt: Does returning to education improve labour market outcomes? International Journal of Lifelong Education, 33(6), 755-769. https://doi.org/10.1080/02601370.2014.971893

Chesters, J., \& Watson, L. (2014). Returns to education for those returning to education: Evidence from Australia. Studies in Higher Education, 39(9), 16341648. https://doi.org/10.1080/03075079.2013.801422 
Council of Higher Education. (2013). 2013 higher education data: Participation Council of Higher Education. Retrieved from http://www.che.ac.za/focus areas/ highereducation/2013/participation

Council of Higher Education. (2017). VitalStats: Public higher education 2015. Pretoria, South Africa: Council on Higher Edcation.

Fragoso, A., Gonçalves, T., Ribeiro, C.M., Monteiro, R., Quintas, H., Bago, J., Fonseca, H.M.A.C., \& Santos, L. (2013). The transition of mature students to highe education: Challenging traditional concepts? Studies in the Education of Adults, 45(1), 67-81. https://doi.org/10.1080/02660830.2013.11661642

Gubler, M., Arnold, J., \& Coombs, C. (2014). Organizational boundaries and beyond A new look at the components of a boundaryless career orientation. Caree Development International, 19, 641-667. https://doi.org/10.1108/CDI-112013-0143

Hardin, C.J. (2008). Adult students in higher education: A portrait of transitions. New Directions for Higher Education, 144, 49-57. https://doi.org/10.1002/he.325

Higher Education Statistical Agency (HESA). (2012/13). Chart 6: Age distribution of first year UK domiciled first degree students (sourced from Table $\mathrm{H}$ [xlsx $12 \mathrm{~KB}]$ ). Retrieved from https://www.hesa.ac.uk/component/content/article?id=3129

Holland, J.L. (1985). The self-directed search: A guide to educational and vocationa planning. Odessa, FL: Psychological Assessment Resources.

Holland, J.L. (1997). Making vocational choices: A theory of vocational personalities and work environments (3rd edn.). Odessa, FL: Psychological Assessment Resources.

Jain, A. (2014). Second career: An eventual need in today's world. In G. Arulmani, A.J. Bakshi, F.T.L. Leong, \& A.G. Watts (Eds.), Handbook of career development: International perspectives (pp. 291-305). Dordrecht, The Netherlands: Springer.

Lincoln, Y.S., \& Guba, E.G. (1985). Naturalistic inquiry. Newbury Park, CA: Sage.

Marshall, C., \& Rossman, G.B. (2014). Designing qualitative research (6th edn.). Singapore: Sage.

McMahon, M., Bimrose, J., Watson, M., \& Abkhezr, P. (submitted). Storytelling and quantitative career assessment: An integrative process.

McMahon, M., \& Watson, M. (2010). Storytelling: Moving from thin stories to thick and rich stories. In K. Maree (Ed.), Career counselling: Methods that work (pp. 53-63). Cape Town, South Africa: Juta.

McMahon, M., \& Watson, M. (2012). Telling stories of career assessment. Journal of Career Assessment, 20(4), 440-451. https://doi.org/10.1177/1069072712448999

McMahon, M., Watson, M., Chetty, C., \& Hoelson, C. (2012a). Examining process constructs of narrative career counselling: An exploratory case study. British Journal of Guidance and Counselling, 40, 127-141. https://doi.org/10.1080/0306 9885.2011.646949

McMahon, M., Watson, M., Chetty, C., \& Hoelson, C. (2012b). Story telling, caree assessment and career counselling: A higher education case study. South African Journal of Higher Education, 26(4), 729-741.

McMahon, M., Watson, M., \& Patton, W. (2014). Context-resonant systems perspectives in career theory. In G. Arulmani, A.J. Bakshi, F.T.L. Leong, \& A.G. Watts (Eds.), Handbook of career development: International Perspectives (pp. 29-41). New York: Springer.

Montgomery, L.E.A., Tansey, E.A., \& Roe, S.M. (2009). The characteristics and experiences of mature nursing students. Nursing Standard, 23(20), 35-40. https://doi.org/10.7748/ns.23.20.35.s52
Patton, W., \& McMahon, M. (2014). Career development and systems theory: Connecting theory and practice (3rd edn.). Rotterdam, The Netherlands: Sense.

Reid, H. (2017). Usefulness and truthfulness: Reviewing the limitations and promoting the benefits of constructivist approaches for career counselling. In M. McMahon (Ed.), Career counselling: Constructivist approaches (pp. 29-39). London: Routledge.

Rottinghaus, P.J., \& Eshelman, A.J. (2015). Integrative approaches to career intervention. In P.J. Hartung, M.L. Savickas, \& W.B. Walsh (Eds.), APA handbook of career intervention: Volume 2: Applications (pp. 25-39). Washington, DC: American Psychological Association.

Sampson, J.P., Peterson, G.W., Osborn, D.S., \& Hayden, S.C.W. (2015). Using caree theory to integrate qualitative and quantitative career assessment. In M. McMahon \& M. Watson (Eds.), Career assessment: Qualitative approaches (pp. 181-190). Rotterdam, The Netherlands: Sense.

Savickas, M.L. (1993). Career counseling in the postmodern era. Journal of Cognitive Psychotherapy: An International Quarterly, 7, 205-215.

Schooreel, T., Shockley, K.M., \& Verbruggen, M. (2017). What if people's private life constrained their career decisions? Examining the relationship between home-tocareer interference and career satisfaction. Career Development International, 22 124-141. https://doi.org/10.1108/CDI-03-2016-0037

Sharf, R.S. (2013). Advances in theories of career development. In W.B. Walsh M.L. Savickas, \& P.J. Hartung (Eds.), Handbook of vocational psychology: Theory, research and practice (pp. 3-32). New York: Routledge.

Shears, M., \& Harvey-Beavis, A. (2006). Self-directed search occupations finder form $R$ (2nd Australian edn.). Melbourne, Australia: Australian Council for Educational Research.

Stevenson, J., \& Clegg, S. (2013). 'My past is a double edge sword': Temporality and reflexivity in mature learners. Studies in Continuing Education, 35(1), 17-29. https://doi.org/10.1080/0158037X.2012.684794

Tuckett, A. (2017). The rise and fall of life-wide learning for adults in England. International Journal of Lifelong Education, 36, 230-249. https://doi.org/10.1080 /02601370.2017.1274546

Watson, M. (2017). Bridging quantitative and qualitative career assessment: The Integrative Structured Interview process. In M. McMahon (Ed.), Career counselling: Constructivist approaches (pp. 260-269). London: Routledge.

Watson, M., \& McMahon, M. (2014). Making meaning of quantitative assessment in career counseling through a storytelling approach. In G. Arulmani, A.J. Bakshi, F.T.L. Leong, \& A.G. Watts (Eds.), Handbook of career development: Internationa perspectives (pp. 631-644). New York: Springer.

Watson, M., \& McMahon, M. (2015). Integrative Structured Interview Process. In M. McMahon \& M. Watson (Eds.), Career assessment: Qualitative approaches (pp. 199-205). Rotterdam, The Netherlands: Sense.

Watson, M.B., \& Stead, G.B. (2017). On overview of career theory. In G.B. Stead \& M. B. Watson (Eds.), Career psychology in the South African context (3rd ed. pp. 21-47). Pretoria, South Africa: Van Schaik.

Yin, R.K. (2014). Case study research: Design and methods (5th edn.). Los Angeles, CA: Sage.

Zytowski, D.W. (2006). Super's work value inventory revised: Technical manual. Adel, IA: Kuder.

Zytowski, D.W. (2015). Test interpretation: Talking with people about their test results. In P.J. Hartung, M.L. Savickas, \& W.B. Walsh (Eds.), APA handbook of career intervention: Volume 2: Applications (pp. 3-10). Washington, DC: American Psychological Association. 


\section{Appendix 1 Integrative Structured Interview (ISI): Questions for the Self-Directed Search}

\section{Crafting a story about the code letters (3)}

1. What is your three-letter code?

2. How would you explain each of these letters?

3. How would you explain the order of your three-letter code?

\section{Crafting a story about the code order (2)}

4. If you were to locate your letter on a scale of 1 to 10 where I was least important and 10 was most important, where would you locate the first letter, the second letter, and the third letter?

5. How do you interpret the location of your letter on the scale? For example, are they close together, evenly spaced, or far apart?

\section{Crafting a story about the code letters in life contexts (4)}

6. In what ways is the first letter of your code evident in your life?

7. In what ways is the second letter of your code evident in your life?

8. In what ways is the third letter of your code evident in your life?
9. What relationships do you see between your three-letters and various facets of your life, such as your work, learning, and other life roles?

\section{Crafting a story about the code letters through personal reflection (1)}

10. What personal qualities have you identified in your reflection so far that are most important to you?

\section{Crafting a story about the code letters in work contexts (2)}

11. If in general the dominant letter code for your profession is ..., what proportion of your work would reflect that letter? What work responsibilities do you have that accord with that letter? What letters would describe the other major responsibilities of your work role?

12. Of all your work responsibilities which do you find most satisfying or rewarding, and which are least satisfying and rewarding, and how do you relate these to your three-letter code?

\section{Crafting an integrative future story using the self-directed search code and past and present experience (1)}

13. Based on your reflection in the previous questions, what could you look for in future work opportunities in order to achieve greater work satisfaction?

(C) McMahon and Watson (2010). 